\title{
EchoGéo
}

$23 \mid 2013$

Entre l'ancien et le nouveau monde. La transcendance du lieu et de l'espace en géographie vinicole contemporaine

\section{An Overview of the Fluctuating Fortunes of Viticulture in England and Wales}

\section{Hugh Clout}

\section{OpenEdition \\ Journals}

Édition électronique

URL : https://journals.openedition.org/echogeo/13333

DOI : $10.4000 /$ echogeo. 13333

ISSN : 1963-1197

Éditeur

Pôle de recherche pour l'organisation et la diffusion de l'information géographique (CNRS UMR 8586)

\section{Référence électronique}

Hugh Clout, «An Overview of the Fluctuating Fortunes of Viticulture in England and Wales », EchoGéo [En ligne], 23 | 2013, mis en ligne le 05 juin 2013, consulté le 10 août 2021. URL : http:// journals.openedition.org/echogeo/13333; DOI : https://doi.org/10.4000/echogeo.13333

Ce document a été généré automatiquement le 10 août 2021.

EchoGéo est mis à disposition selon les termes de la licence Creative Commons Attribution - Pas d'Utilisation Commerciale - Pas de Modification 4.0 International (CC BY-NC-ND) 


\section{An Overview of the Fluctuating Fortunes of Viticulture in England and Wales}

Hugh Clout

\section{Introduction}

1 With only 1384 ha of vineyard in 2011 and an average annual production of $20000 \mathrm{hl}$ of still and sparkling wines, England and Wales bear no comparison with the extensive and highly productive wine-making countries of continental Europe and the southern hemisphere (English Wine Producers, 2011; Pitte, 2000). Nonetheless, the seemingly 'impossible' environments north of the English Channel have a long history of viticulture, and the wines that they produce occupy interesting niche markets that are very different from those occupied by the quality wines of Bordeaux or the massproduced wines of Australia, New Zealand, South Africa or South America (Pitte, 1990, 2004; Banks \& Overton, 2010, p. 61). This overview article sketches the history of English viticulture before summarizing changes following its revival after 1945. Attention is then directed to the role of key pioneers and producers in English viticulture, and to the development of 'vineyard tourism' in recent years.

\section{The Historical Background to Viticulture in England and Wales}

2 There is no indisputable evidence that vines were grown on the island of Britannia before the Roman conquest in $43 \mathrm{AD}$, however wine amphorae pre-dating the invasion have been found at various sites in southern England resulting from cross-Channel trade with France (Skelton, 2001). Subsequently, wine drinking formed an important aspect of Roman culture, with archaeological evidence of amphorae and drinking cups having been found at many sites of Roman villas and garrison settlements in Britain. In 
addition, implements that could have been used for pruning vines have been found at many southern locations, but whether vines were grown in Britain or reliance was placed entirely on imports remained unclear and has formed a topic of controversy (Williams, 1977). However, recent archaeological investigations of a 35 ha RomanoBritish site in the Nene valley in Northamptonshire have discovered deposits of grapevine pollen dating from Roman times and have revealed ground features that suggest the layout of a vineyard (Brown \& Meadows, 2000; Brown et al., 2001). If, therefore, vines were being grown in the eastern Midlands it is very likely that they were also being produced in warmer localities in southern Britain. With the spread of Christianity toward the end of the Roman period, either imported or home produced wines were used in religious ceremonies, but with the retreat of the Romans in the late fourth century AD and the invasion of Angles, Saxons and Jutes from northern Europe it is probable that surviving vineyards were abandoned. During the sixth century, Christianity spread in the south and east of what had become England and trade with mainland Europe revived. If viticulture was practised in southern England it would have been on an extremely modest scale. In the late eighth century, Christian religious centres were attacked as Vikings invaded England and the viticultural tradition was further eroded. Defeat of the Danes by King Alfred in the late ninth century led to a revival of Christianity and there is documentary evidence of viticulture and winemaking at some monasteries in southern England (Hooke, 1990). This revival coincided with the onset of the medieval warming phase in global climate that lasted from ca. 900 to ca. 1300 . The great enquiry ordered by William I - or 'William the Conqueror' as he is known in England - that was reported in the Domesday Book of 1086 recorded vineyards in forty-two locations of late Anglo-Saxon England, notably in south-eastern and south-central areas and in East Anglia, a few of which were described as being newly planted (Unwin, 1990; Darby, 1977; Darby \& Campbell, 1962). One-third of all Domesday vineyards were attached to monasteries, with the remainder located on property held by members of the nobility.

3 The Norman conquest, with the subsequent arrival of nobles and clerics from France, heralded an important phase for the development of viticulture in many sunny, welldrained locations across southern half of England, from Worcestershire in the west to Kent in the east (Unwin, 1990). A growing demand for wine was met, in part, by imports from France. Importation greatly increased after the marriage in 1152 of Henry II to Eleanor of Aquitaine, previously wife of Louis VII of France, which brought the vineyards of the Bordelais under the English crown until 1453 (Carus-Wilson, 1947; Richardson \& Dennis, 2003). Shipping of fine claret wine from Bordeaux and neighbouring ports to London and the southern ports of England was encouraged by Henry as he sought to consolidate his hold on Aquitaine (Williams, 1936, p. 271; Pelham, 1936, p. 323). The flourishing wine trade required more ships to be built that could be commandeered for naval rather than commercial purposes, and enabled tax revenues to be increased as levies were raised on all shipments of wine at their port of entry to England (Ordish, 1977, p. 31). Importing rather than producing wine released land for growing foodstuffs for England's rapidly increasing population. Nonetheless, viticulture continued to be practised on many properties owned by religious institutions but this was threatened as the climate became wetter, summers cooler and winters milder thereby hampering the ripening of grapes and encouraging fungal diseases. Social and economic disruption in the quarter century following the Black Death (1348) reduced the volume of manpower available to monasteries that began to lease out their land 
rather than working it on their own account. Needing to pay rents, their new tenants turned to short-term cash crops rather than producing vines. By the early fifteenth century, the implications of the so-called 'Little Ice Age' that lasted until ca. 1800 were beginning to be felt. Many religious institutions abandoned viticulture prior to the Dissolution of the Monasteries starting in 1536 that led to major changes in landownership and further accentuated the decline.

Despite this trend, some vineyards remained in the seventeenth century and a few new ones were planted. For example, James I, who ruled England from 1603 to 1625, had vineyards planted on his estate at Oaklands Park, near Weybridge, in Surrey. At roughly the same time, Marie de Medici donated 10000 vines to Lord Salisbury for planting on his property at Hatfield in Hertfordshire, and in 1610, the botanist John Tradescant planted 20000 vines on the same property (Ambrosoli, 1997, p. 298-299). In 1666 John Rose, gardener to Charles II, wrote The English Vineyard Vindicated, in which he considered such issues as site selection, grape varieties, pruning and harvesting. In 1740 , Charles Hamilton planted a vineyard at Painshill Place in Surrey that acquired a fine reputation, but this ceased production in the late nineteenth century. Landowners realized not only that the quality and quantity of their grapes varied greatly year by year under the English climate, but also that the nation's taste for wine was changing toward sweet, heavy imperial wines shipped from Australia and South Africa. In 1875, Lord Bute launched the last experiment in commercial viticulture, prior to the recent revival, when a few hectares were planted at Castle Coch in South Wales. This tiny vineyard flourished for a while but its last successful vintage was in 1911 and its vines were grubbed up in 1920. Thereafter, isolated vines continued to grow against sunny walls in many parts of southern England but attempts at commercial viticulture had come to a halt. All that remained of its legacy was the survival of place names relating to vines, vineyards, and wine.

\section{The Role of Pioneers in the Post-War Revival}

The renaissance of viticulture may be traced to the efforts of three individuals who sought to prove that vineyards could flourish under English climatic conditions, and that drinkable wines could be made from the grapes they yielded. In 1946, Ray Barrington Brock set up a viticultural research station at his own expense at Oxted in Surrey (Ordish, 1977, p. 49). During the following quarter century this enthusiast trialled six hundred table and wine grape varieties, using vines and cuttings obtained from various parts of Europe and the United States. His collection would prove vitally important for the revival of viticulture in England and Wales. As Britain slowly emerged from post-war austerity, some of its citizens started to become interested in viticulture, and nurserymen sensed the emergence of a new market for outdoor vines. Varieties described as suitable for the open vineyard were sold, but few tests were made of whether they were really appropriate for the English climate. George Ordish (1977, p. 49) recalled: "In some cases, large stocks of what were supposed to be early varieties were simply purchased on the continent and resold in Britain. Foreign nurserymen sometimes delivered wrongly named material, probably thinking that in England - land of perpetual fog - the vines would not grow and ... if they did grow the phylloxera would soon kill them, so it did not matter what was sent". Some pioneers were disheartened but certain good cultivars were sent from mainland Europe. 
Barrington Brock held open days at Oxted and published reports outlining what might be achieved (Brock, 1949). Among his early tasks was the need to sort out varietal synonyms, to identify misnaming, and to dispel false information peddled in the literature. In order to demonstrate how wine should be made, he built a winery at Oxted and sought advice from many quarters, for example on sourcing the correct yeast culture for the wine-making practices being employed. Barrington Brock also sought to clarify the taxes that Customs and Excise authorities would levy on English and Welsh wines. His research centre proved immensely popular, indeed "the modern revival of vineyards ... would not have got off the ground so quickly without the Oxted station. Its reports formed a guide to the growing band of would-be vignerons, both amateurs making wine for their own use and larger operators producing it for sale" (Ordish, 1977, p. 50). Vines obtained from Oxted were used at many of the earliest vineyards to be planted. During the 1950s and 1960s, Barrington Brock received, and replied to, thousands of enquiries each year but, despite selling vines of promising varieties, he was not able to cover running costs. Never obtaining a government subsidy, his experimental station closed after operating for twenty-five years. A less exposed site at a lower elevation might have been a better location for his experiments but he argued that any grape variety performing well at oxted would ripen virtually anywhere in southern England.

6 The second individual to pioneer the post-war revival was Edward Hyams, who was released from naval service in 1946 and settled in Kent. During 1947-48, he planted some vines for making wine, using some of the sources identified by Barrington Brock. The two men sought out old examples of vine growing in England and discovered a vine at Wrotham (Kent) resembling the Pinot Meunier variety. Perhaps Hyams's greatest contribution was as a writer and broadcaster. In 1949, he published The Grape Vine in England, and four years later edited Vineyards in England that contained a score of chapters by specialists on many aspects of English viticulture past and present (Hyams, 1949, 1953). The third important individual to promote the revival was George Ordish who trained as an entomologist and an economist, and investigated pests and diseases in many parts of the world. One of his early entomological projects took him to the Champagne region and upon returning to his native Kent he compared climatic and environmental characteristics in the two areas. He found that the Kentish climate was very similar to that of the Champagne, except that Kent had milder winters. In addition, he too discovered many old houses in southern England with rather miserable vines growing on their walls, not as a result of the climate but because of attacks of American powdery mildew, which could be controlled by application of sulphur. As early as 1938, Ordish had planted a few vines in his garden near Maidstone from which he produced good wine. After 1945, he became good friends with Barrington Brock and Edward Hyams, and began to write and broadcast about the prospects for viticulture in England and Wales. His first book, Wine Growing in England (1953) included a rudimentary cost-benefit analysis of planting an acre ( $0,4 \mathrm{ha})$ with vines. His ambitious book on The Great Wine Blight (1972) traced the devastating impact of phylloxera on viticulture on the continent of Europe, and was followed by Vineyards in England Wales (1977). This text summarized historical features and environmental challenges (including site orientation, soil, climate, pruning and planting) before examining pests and pest control, and the practicalities of wine making. According to the Ministry of Agriculture, only sixteen cases of phylloxera were recorded in England and Wales 
between 1863 and 1956, and in each instance the disease was eliminated by destroying the diseased vines and those adjacent to them (Ordish 1977, p. 89).

7 Accompanying the work of these pioneers was the creation, in 1951, of a tiny vineyard (1,2 ha) at Hambledon in Hampshire by Major-General Sir Guy Salisbury-Jones. This was the first vineyard planted for producing wine for sale since the Castle Coch venture three-quarters of century earlier. Following a visit to Oxted, Salisbury-Jones planted the Seyval Blanc variety and made his first wine in 1954, which gave rise to great interest in the English press. A second commercial vineyard, covering less than 1 ha, was opened at Heathfield in Sussex by Jack L. Ward, who planted Müller-Thurgau and other Germanic varieties in 1955. Ward's 'Merrydown' company already produced a strong cider and various drinks made from gooseberries and other fruits (Ordish 1977, p.52). In later years, Ward introduced Reichensteiner, Huxelrebe and Schönburger varieties to England Wales. In 1957, Lieutenant-Colonel and Mrs. Gore-Brown planted a third new vineyard at Beaulieu in Hampshire, which covered 3 ha in 1960. With the help of Anton Massel, a young German who had already assisted Salisbury-Jones, the Gore-Browns installed a modern vinery and proceeded to make very good wine. In later years, Massel would establish his own vineyard and oenological research station at Ockley (Surrey) from which sound professional advice was provided. To be successful and produce a respectable wine, these and subsequent growers had to plant the right varieties of grape to suit the local environment, and needed to understand the scientific processes in wine making. In addition, ingrained prejudices against English wine, which was sometimes confused with 'British wine' made from imported grape concentrates, had to be dispelled from public perception (O'Brien, 2011). In this respect, Salisbury-Jones, Marshal of the Diplomatic Corps in London, took a lead by serving and selling high-quality table wines made from grapes grown in his Hambledon vineyard. He was the first president of the English Vineyards Association (now the UKVA) that was founded to represent the interests of English vignerons, and Jack Ward was its first chairman.

\section{Trends in Planting and Production}

During the 1960s and 1970s, the planting of new vineyards accelerated in England Wales, with the English Vineyards Association estimating that the surface under vines had risen to 196 ha in 1975, however Ordish quoted a more conservative figure of 125 ha (Ordish, 1977, p. 53). During the subsequent decade, the area under vines increased to 500 ha in 1985 (of which 370 ha were in production) on more than 300 vineyards. This upward trend was set to continue following the production of over two million bottles of wine at 120 wineries in 1983 resulting from especially favourable weather conditions in that year (Ilbery, 1985, p. 147). Unsurprisingly, vineyards were most numerous in south-eastern and south-central England, but one vineyard was located as far north as Yorkshire. A survey undertaken in 1983 confirmed the very small mean size of vineyard in England Wales, and revealed that less than half of the holdings containing vineyards were devoted solely to the growing of grapes, with the remainder combining viticulture with fruit growing, hop farming, other agricultural work or off-farm activities (Ilbery 1985, p. 147). Four-fifths of the growers owned their vineyards and three-quarters of growers had received public-school or university education, a much higher proportion than among agricultural operators as a whole. 
Most of the people who had been attracted into viticulture belonged to higher socioeconomic groups (professional, teaching, business, engineering, military), whilst others worked in catering, the wine trade, horticulture, or farming. Thus, in England and Wales in the mid-1980s, "viticulture would appear to be an enterprise practised by enthusiasts with an interest in and fascination for wines, and who have the necessary land and/or capital to enable them to satisfy their curiosities" (Ilbery, 1985, p. 150).

During the remainder of the 1980s and early 1990s, landowners continued to perceive viticulture to be an attractive opportunity and planted entirely new vineyards as well as enlarging existing ones. A rumour circulating in 1990-91 that further expansion of viticulture would be banned encouraged an abnormally large planting in the next couple of years (Unwin 1991). By 1993, 479 vineyards (with a mean size of only 2,3 ha) were recorded in England and Wales, involving 1065 ha, of which 760 ha were in production. However, 1993 was a disappointingly wet year and grape harvests were poor. Since England and Wales are among the coolest parts of the world for viticulture, light soils with good natural drainage and appropriate slope and aspect are essential conditions for success. Yet it seems that "the dream of owning and vineyard had led many of the early growers to chose unsuitable locations, such as windswept or frostprone sites with poorly drained soils and, often, poor aspect" (Spellman \& Field, 2002, p. 326). During the 1990s, "growers came to realize that inappropriate soils were directly responsible for poor performance on certain sites, a discovery that led to the rapid reduction in the number of vineyards" and the 'grubbing up' of stretches of vines (Spellman \& Field, 2002, p. 329; Unwin, 1994). Other reasons for abandoning viticulture included frustration with government regulations and what were perceived as unfair taxes on English wines, and a range of personal factors such as ill health, increasing age, and lack of a successor.

Toward the end of the decade, the downward trend went into reverse as cumulative experience resulted in a more careful approach to site selection and management practices. In 2003 there were only 33 vineyards in England Wales covering a total of 770 ha. At this time, viticultural experience led to improvements in finished wine unlike earlier years when "many wines were unfriendly to the palate", being "too acidic, too dry, and lacking fruit and body. This was a result of picking grapes [too early] when levels of natural sugar were too low, or not being able to de-acidify or to balance acidity correctly" in the winemaking process (Spellman \& Field, 2002, p. 329). Increasing mention of the likely implications of 'global warming', with higher summer temperatures in the future, reinforced the attractiveness of England and Wales for viticulture (Spellman, 1999). Until 1992, all still wines had to be classified simply as 'table wines', but introduction of the Quality Wine Scheme enabled a category of wines to be recognised in a similar way to the appellation d'origine contrôlée in France (Boodle, 1992). Regulations were revised in 2004 to differentiate labelling as 'quality wine' (from a specified area), 'regional wine', or 'table wine'.

11 By 2011, the number of vineyards in England and Wales had revived to 419, covering $1384 \mathrm{ha}$, of which almost all (1 $208 \mathrm{ha})$ were in wine production, but the mean size of vineyard was a mere $3,3 \mathrm{ha}$. 
Illustration 1 - Distribution of Vineyards in England and Wales

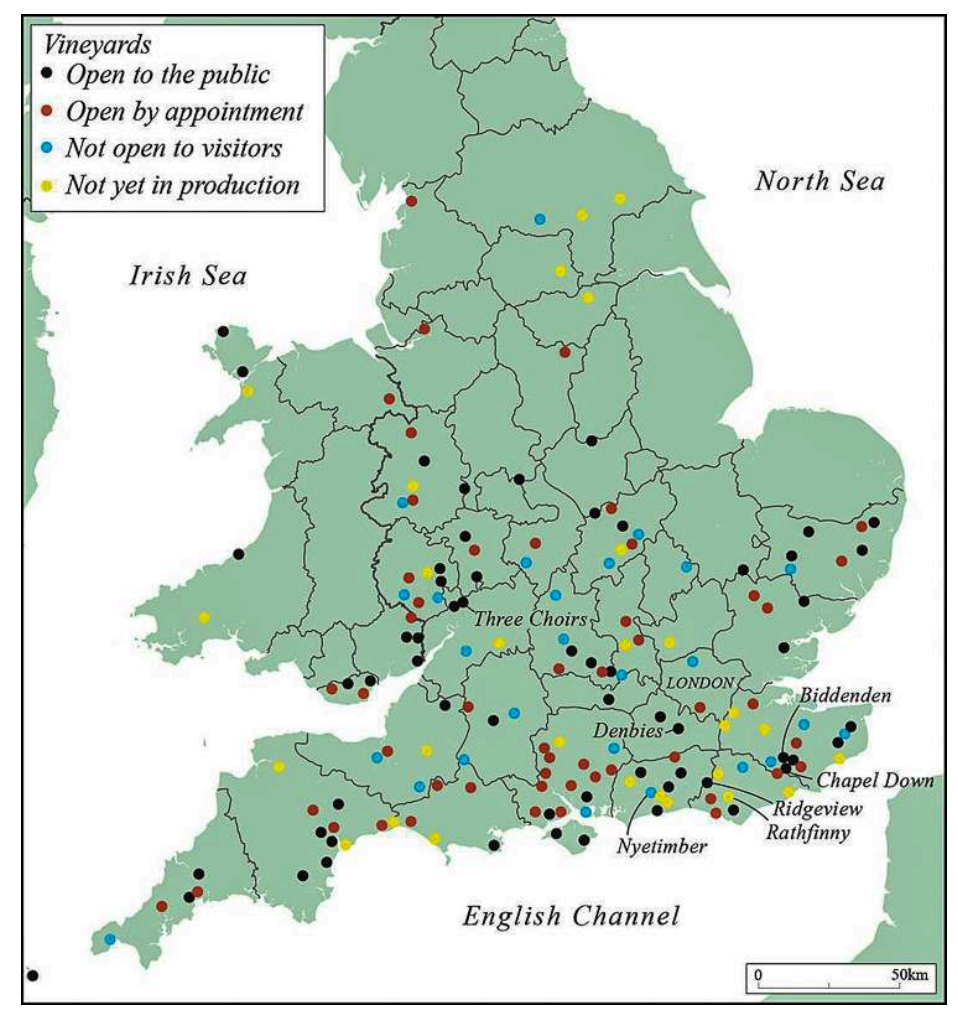

Source: simplified from a map compiled by the United Kingdom Vineyards Association and the English Wine Producers, with additional information, 2010.

12 At this time, 124 wineries were in operation, a total remarkably similar to the figure noted for 1985 (120) but well below that for 1992 (157). The doubling of the surface under wines between 2003 and 2011 was, in part, encouraged by the gradual rise in the number of summer days reaching 29 or 30 degrees $C$, which boosted the natural sugar content of ripening grapes and raised average production levels to more economical levels (Turner, 2010, p. 692). During 2012 England's vineyards were extended with, for example, 57000 vines covering 20 ha being planted on a south-facing slope on Rathfinny Estate located on the South Downs a few kilometres from the coast and sheltered from south-westerly winds. Mark Driver, founder and owner of Rathfinny developed his passion for wine during a visit to New Zealand in 1990. He has set his sights very high, wishing "to create a sparkling wine to rival the best on offer from across the Channel ... I want Rathfinny to be sold not just in the best restaurants in London, but in Paris, New York, Beijing and Hong Kong as well" (http://news.sky.com/ story/5772/largest-vineyard-in-england-takes-root). Rathfinny's manager is a New Zealander with experience of vineyards at Hawkes Bay, and its winemaker originates from Epernay, with experienced gained on estates in the Champagne region and in California.

Over the decades, the grape varieties grown and the types of wine produced underwent notable changes. In the 1960s and 1970s, Liebfraumilch and other Germanic wines had been especially favoured by wine drinkers in the United Kingdom, and the earlier table wines produced from grapes grown on English vineyards were similarly light and fruity. During the 1980s, drier Australian wines were well received by British wine drinkers and table wines produced in England and Wales reflected this change in taste. 
Bottle-fermented sparkling white wines also became increasingly popular among wine drinkers and large areas of English vineyards have been planted with such varieties as Chardonnay and Pinot Noir in recent years. Red wines account for only one-tenth of production in England and Wales, with Rondo and Pinot Noir being favoured grape varieties.

Table 1 - Top Ten Grape Varieties Planted in England and Wales

\begin{tabular}{|l|l|l|l|l|l|l|}
\hline Rank 2010 & Grape Variety & Surface (ha) & \% Surface & Rank 1999 & \% Surface & $\begin{array}{l}\text { Trend } \\
1990-99\end{array}$ \\
\hline 1 & Chardonnay & 249 & 18,8 & 9 & 3,9 & + \\
\hline 2 & Pinot Noir & 248 & 18,7 & 7 & 5,1 & + \\
\hline 3 & Bacchus & 128 & 9,8 & 4 & 9,9 & + \\
\hline 4 & Seyval Blanc & 93 & 7,0 & 3 & 11,7 & - \\
\hline 5 & Reichensteiner & 85 & 6,5 & 2 & 12,3 & - \\
\hline 6 & Müller-Thurgau & 61 & 4,6 & 1 & 13,3 & - \\
\hline 7 & Pinot Meunier & 53 & 4,0 & & & \\
\hline 8 & Madeleine Angevine & 47 & 3,6 & 6 & 6,8 & + \\
\hline 9 & Rondo & 45 & 3,4 & 18 & 1,1 & - \\
\hline 10 & Schönburger & 42 & 3,2 & 5 & 7,9 & - \\
\hline
\end{tabular}

Source: Statistics from English Wines Producers, 2010; and Spellman \& Field, 2002, p. 328.

14 Table I shows that Chardonnay (occupying $18,8 \%$ of the vineyard area) and Pinot Noir $(18,7 \%)$ were the most widely planted grape varieties in 2010 , rising from ninth and seventh position respectively in 1999. In 2010, Bacchus and Seyval Blanc varieties occupied similar rankings to those of 1999, whilst the proportion of English and Welsh vineyards devoted to Müller-Thurgau and Reichensteiner was substantially lower. In the 1950s and 1960s, German consultants had insisted that Müller-Thurgau grapes stood the best chance of ripening in England. Certainly, it is a very vigorous variety that is resistant to frost, but it is susceptible to disease and its large leaves can make for excessive shading, especially in cool, moist years (Kenny \& Harrison, 1992). By contrast, the hybrid Seyval Blanc has remained popular, being easy to grow and resistant to most diseases. Rondo and other red varieties are proving well suited to English conditions and are being cultivated more widely.

\section{Viticultural Enterprises Large and Small}

Most vineyards in England and Wales are extremely small enterprises, but there are also some large operations that are organized in a thoroughly professional way with an 
eye to maximizing profits by producing excellent wines that command high selling prices. The largest of these is the 106 ha vineyard that covers two-fifths of the Denbies Estate located on the chalky soils of the North Downs, near Dorking (Surrey), some $34 \mathrm{~km}$ to the south of the heart of London (illustration 2).

Illustration 2 - Vineyards on the Denbies Estate located on the North Downs, Surrey

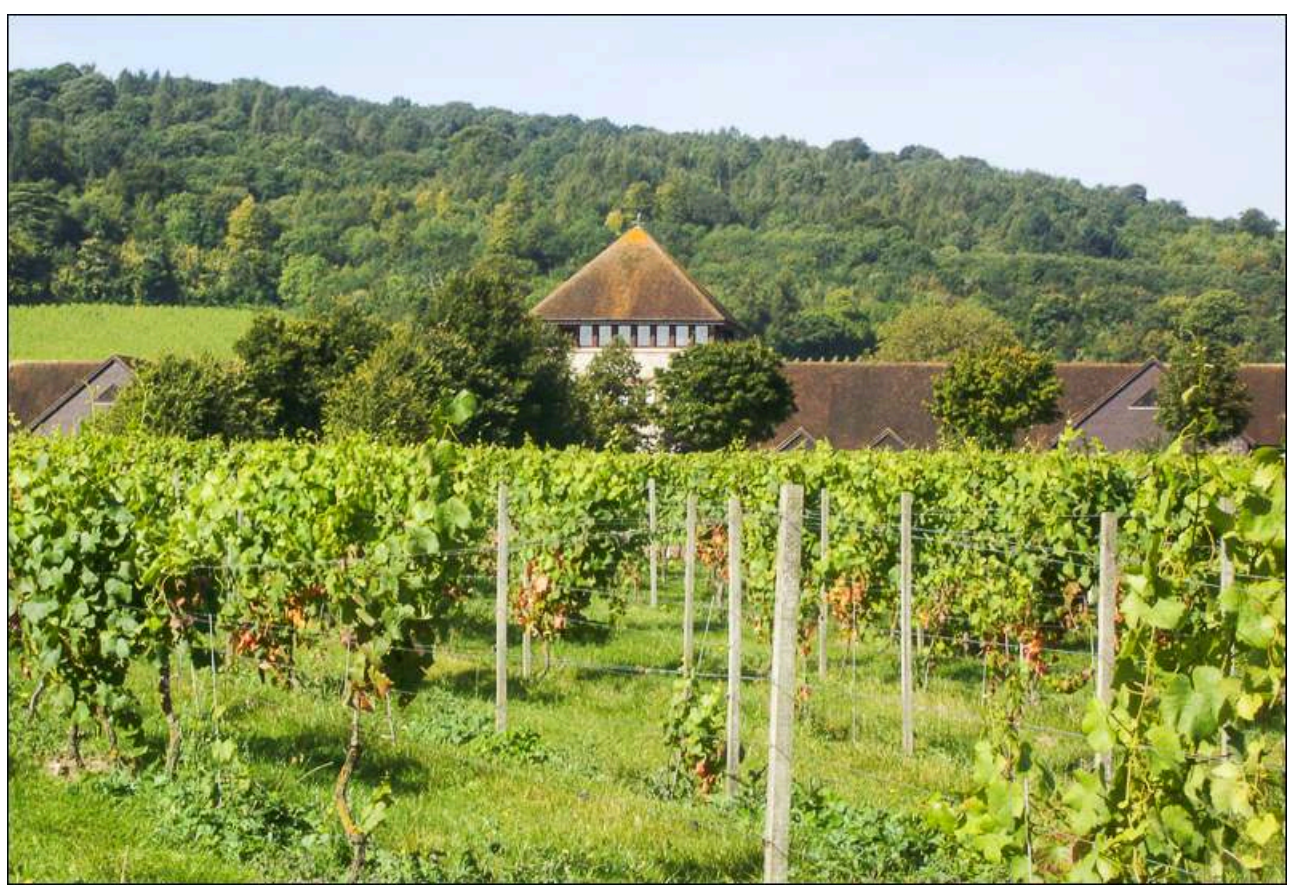

Author: H. Clout, 2012

In 1984, Adrian White, owner of a multinational water treatment company, purchased the property from the fourth Lord Ashcombe and set about devising a strategy for the future management of its farms and woods (Denbies Estate information). Richard Selley, a local geologist, argued that the North Downs and the Champagne region shared a similar rock formation and that the topography of the Denbies Estate, with southerly and south-easterly slopes, made it suitable for the growth of vines (Selley, 2008; Turner, 2010, p. 707). Since these slopes were of little value for grazing, the White family decided to replace the estate's livestock farm with a vineyard. The growing of maize for silage to feed a beef herd was phased out in 1986 and, after obtaining advice from German vine growers, the Denbies vineyard was created over the next five years. Planting was undertaken with great care in order to maximise sunlight and reduce the chance of disease. Since part of the estate had been designated as a Site of Scientific Interest (but not the vineyard), the White family determined that their new venture would be environmentally friendly. Paths and tracks through the estate are regularly maintained and include $11 \mathrm{~km}$ of vineyard trails that are accessible to the public. Roots from the vines help reduce erosion on sloping areas, and the new winery building replaced much less attractive agricultural sheds.

17 As well as growing grapes, producing wine and selling some 400000 bottles each year, the Denbies Estate is strongly committed to 'wine tourism' as a means of generating income. Its 'wine experience' tour has become an important attraction, with around 300000 visitors coming each year, many of whom are retired people or tourists who 
arrive by coach (Denbies Estate Information). The visitors' centre occupies a modern double courtyard building in the local vernacular style (illustration 3).

Illustration 3 - The visitors' centre and winery on the Denbies Estate, Surrey

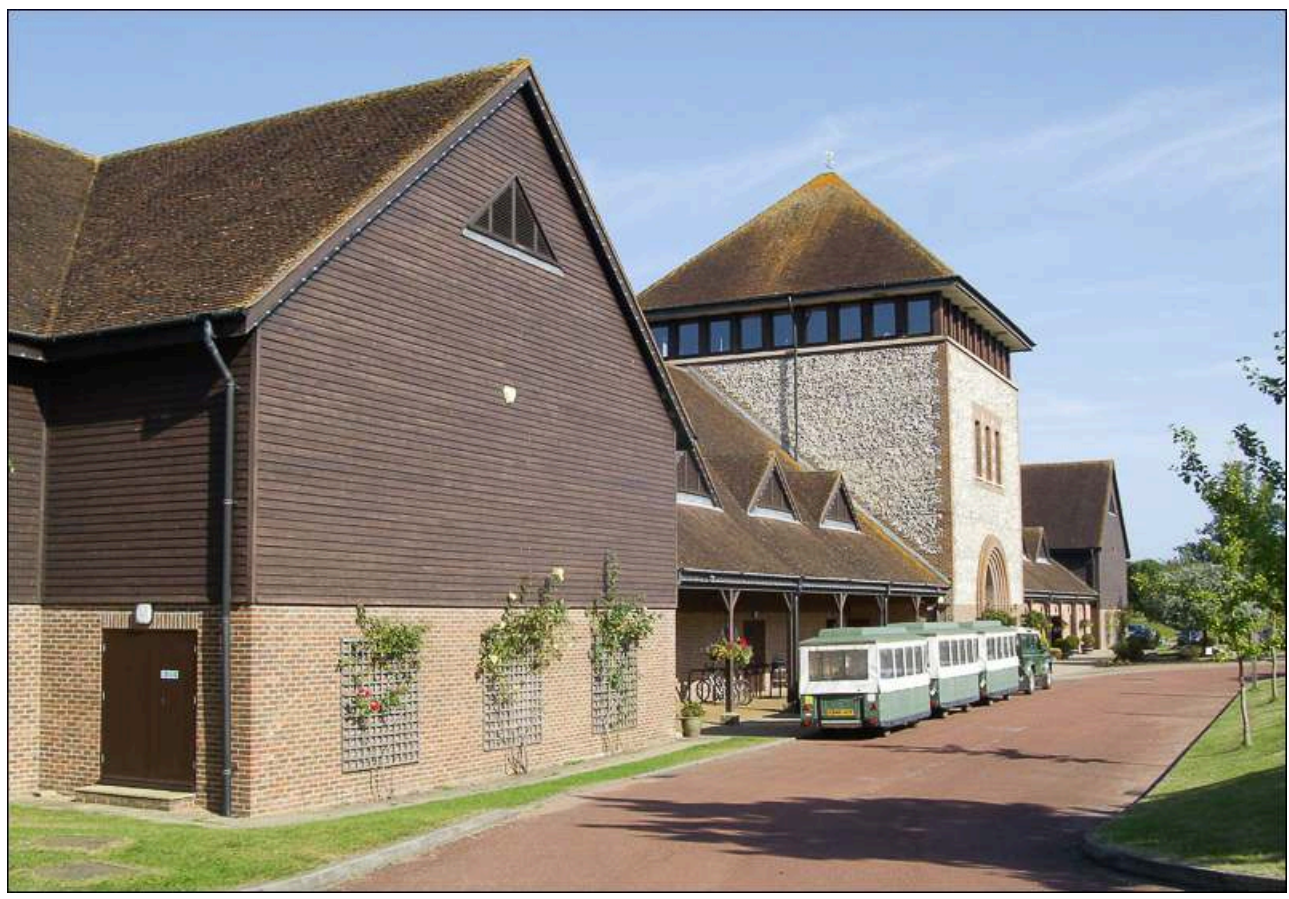

Author: H. Clout, 2012.

Visitors ride through the working winery on a 'people mover', while listening to a commentary, and then go to the wine cellars, the 360 degree cinema, art gallery, lecture room, restaurants, and shop. They receive a guided tour through the vineyard on a 'land train', before sampling Denbies wine in the cellars or in one of the two restaurants. The estate runs a guest house in one of its farmhouses and has a kitchen garden centre, as well as providing venues for exhibitions, conferences, concerts and dances, and catering for weddings and corporate functions (Howley \& Van Westering, 2008). Some visitors will take the opportunity to visit the adjacent Surrey Hills Brewery to learn about brewing and to purchase local beer. With its many activities Denbies is a significant source of employment, involving 80 staff in winter and up to 110 in the summer high season. Two-thirds of the wine produced on the estate is sold at the visitors' centre, the remainder being sold through supermarkets and wholesalers, or by mail order. About two-thirds of purchasers are over 50 years of age and most come from within a $40 \mathrm{~km}$ radius of the estate, a catchment areas covering greater London as well as the affluent county of Surrey. In 2000, Denbies launched a new wine range with award-winning labelling and these new products have led to an increase in sales to younger purchasers (Richardson \& Dennis, 2003). The estate's marketing strategy emphasises the wine tourism side of the business, which in turn generates wine sales. Like other leading producers, Denbies participates in set events in the English Wine calendar, including the English Wine Tasting held in London on St. George's Day (23 April) for buyers and wine writers, the English Wine Week in May or June, and the English Wine Festival in September. In addition, the estate's wine are sold at farmers' markets, country fairs and exhibitions in neighbouring areas. 

English Wines Group, producing 500000 bottles each year that are marketed as 'Chapel Down Wines' (Turner, 2010, p. 704). The company was founded in 1992 by David Cowderoy who came from an English wine making family and had taken a wine making course in Australia. Chapel Down has a 9 ha vineyard near Tenterden in Kent and has contractual relationships, normally of twenty years, with two dozen vineyards in south-east England, covering a further 100 ha, to supply grapes to its winery. Under Frazer Thompson, who became managing director in 2002, the Chapel Down strategy emphasized producing high-quality wines and marketing them at prices that reflect their reputation. Since then, many of the old Germanic varieties have been 'grubbed up' at the home vineyard, keeping only those that produce consistently high quality grapes, and planting noble French varieties such as Chardonnay and Pinot Noir has been increased. Owners of vineyards in the supply network have been encouraged to steer their production toward premium grape varieties, particularly those used in making sparkling, Champagne-like wines. The Chapel Down home site welcomes visitors to stroll around its vineyard and herb garden, and offers guided tours of the vines and winery, followed by wine tasting (Illustration 4).

Illustration 4 - The restaurant, shop and winery on the Chapel Down vineyard, Kent

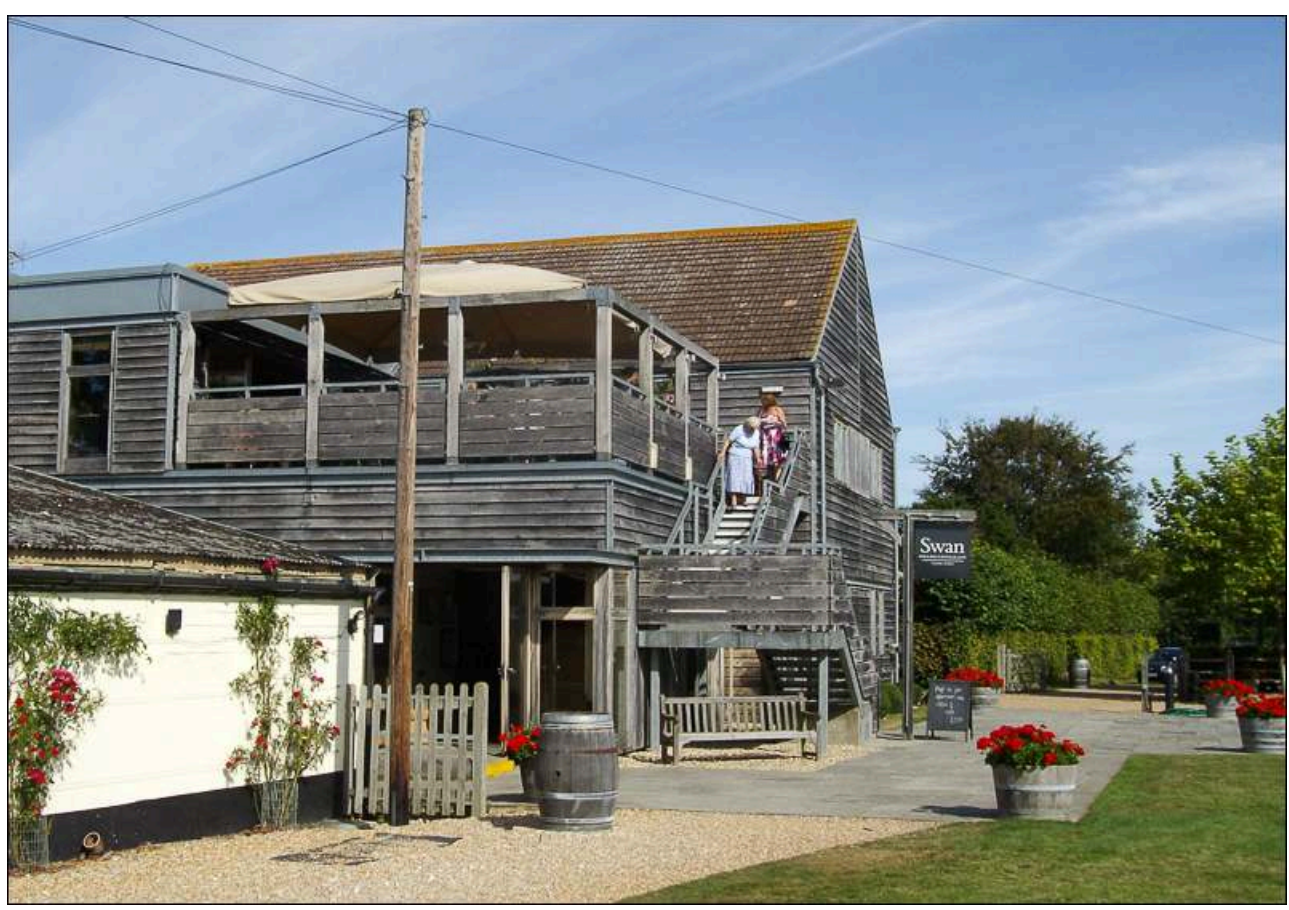

Author: H. Clout, 2012.

It has a restaurant serving "the finest local and seasonal produce, in beautiful surroundings", and its "wine and fine food store features the full range of Chapel Down wines plus the very best of English food and drink" (Chapel Down brochure). A $5 \mathrm{~km}$ itinerary from the home site joins part of the High Weald Landscape Trail, located within the High Weald Area of Outstanding Natural Beauty.

21 The drive for excellence may also be exemplified by the Nyetimber and RidgeView vineyards in Sussex. In 1987, Stuart and Sandy Moss moved to England from Chicago with the objective of growing grapes that would yield premium-quality, Champagne- 
like wines (Turner 2010, p.701). With large capital resources, but no previous experience of viticulture, they selected a site with soils and climate comparable to those of the Champagne region, planted the appropriate varieties of vine (Pinot Noir, Pinot Meunier, and Chardonnay) on their 9 ha Nyetimber vineyard, and imported wine making equipment from Epernay. Sandy Moss took a specialist course in wine making at Plumpton College (near Lewes in Sussex), worked at wineries in the Champagne, and sought advice from renowned oenologist, Jean-Manuel Jacquinot. Under new ownership, the enterprise has been enlarged in recent years and has planted new vineyards in West Sussex and Hampshire. Like a number of other English vineyards, Nyetimber is not open to visitors. The development of RidgeView vineyard displayed many similarities, with Michael and Christine Roberts investing very substantial resources from the sale of their information technology company to purchase a $12 \mathrm{ha}$ estate in 1993 on which visitors are welcome during most of the year (O'Brien, 2011). With advice from consultants in Epernay, classical Champagne grape varieties were planted, and a cutting-edge winery was established using equipment from France. RidgeView voluntarily follows rules set by the Comité Interprofessionnel $d u$ Vin de Champagne regarding wine making practices, control of grape varieties, production yields, pressing techniques, and ageing periods. Setting their sights extremely high, both Nyetimber and RidgeView have met their objectives and price their sparkling wines between the expensive French champagnes and cheap, tank-fermented Italian and Spanish products. Both vineyards have won blind-tasting awards in France and elsewhere, and can compete effectively in the middle range sector of Champagne-like sparkling wines (Richardson \& Dennis, 2003). Ever conscious of maintaining the quality of their product, in October 2012 the winemaker at Nyetimber declared: "we have collectively come to the decision that [because of bad weather] the grapes from 2012 cannot deliver the standards we have achieved in the past" hence no grapes would be harvested from that vineyard (Meikle, 2012, p. 7). Other vinegrowers reported a serious fall in yields and feared that 2012 might be a disappearing vintage.

\section{Vineyard Tourism}

Denbies, Nyetimber, RidgeView and other commercial enterprises distinguish themselves from the great majority of vineyards in England and Wales, which are very small indeed. Only a quarter of vineyards have their own wine making facilities, lacking sufficient capital to invest in high technology equipment that ferments grape juice to produce premium quality wine. However, a number of vineyards right across the size range offer some kind of visitor experience, in the form of vineyard trails, guided visits, refreshments, sampling and sale of wine, and even accommodation in local farmhouses. For example, the Biddenden vineyard in the Kentish Weald provides an imaginative array of possibilities. Started by the Barnes family in 1969 on a former apple orchard, the vineyard now covers 9 ha. As well as guided tours of the vines, winery and cidermaking facilities, visitors are offered the possibility of also visiting a brewery, a dairy making cheese, a landscape garden, or a hop farm with attractive oast houses, and even of spending part of their trip travelling on a local narrow-gauge railway or on a line with a restored steam train (Biddenden Vineyard brochure) (illustration 5). 
Illustration 5 - Dutch visitors at the Biddenden vineyard as part of their tour through the countryside of Kent

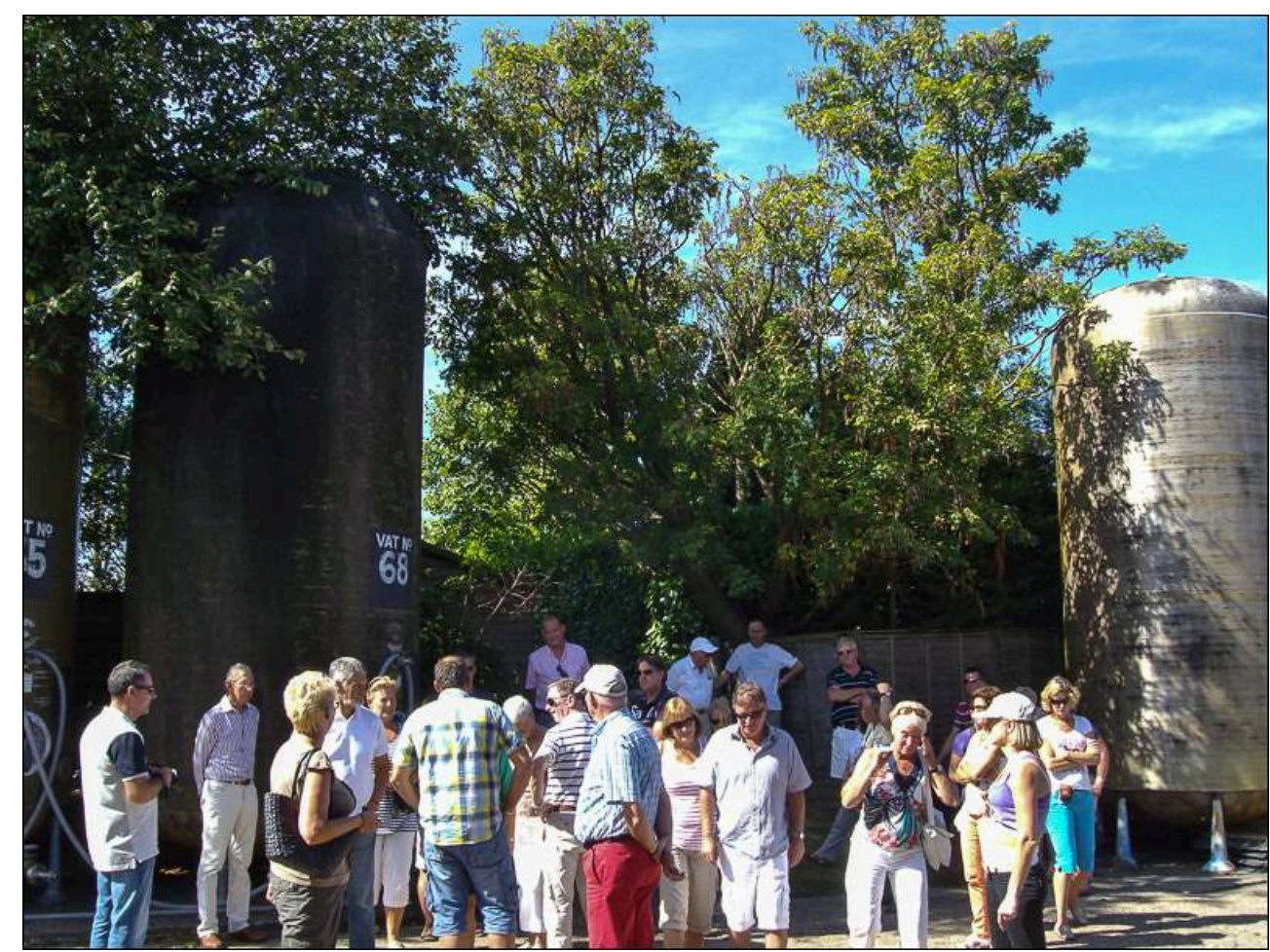

Author: H. Clout, 2012.

In Gloucestershire, the Three Choirs vineyard, first planted in 1973, now processes grapes from twenty-five vineyards under contract to its winery. Three Choirs offers tours throughout the year and has a high-class restaurant, a hotel and a shop that sells wine spanning a range of prices (Richardson \& Dennis, 2003). As well as a shop and restaurant, the Godstone vineyard in Surrey, planted by the Deeley family in 1985, offers a fishing lake among its attractions.

Such imaginative approaches are relatively unusual. Not all vineyards that are opened to the public are signposted adequately, and the potential for devising a 'vineyard route' in the Weald remains to be realized. When compared with their counterparts in France, California, Australia and New Zealand, it would seem that most English wine producers are not organized sufficiently to derive the maximum benefit from tourism (Carlsen, 2004; Howley \& Van Westering, 2008). Some small vinegrowers cannot afford to release - or take on - the necessary labour to cope with visitors, whilst a number of commercial operators remain closed to visitors whose presence would detract from their prime business of growing high-quality grapes and making premium wine. On some of these vineyards the premises for selling wine are very small (illustratiuon 6). 
Illustration 6 - The very small retail counter of the Sandhurst vineyard in a building on Hoads Farm, Kent

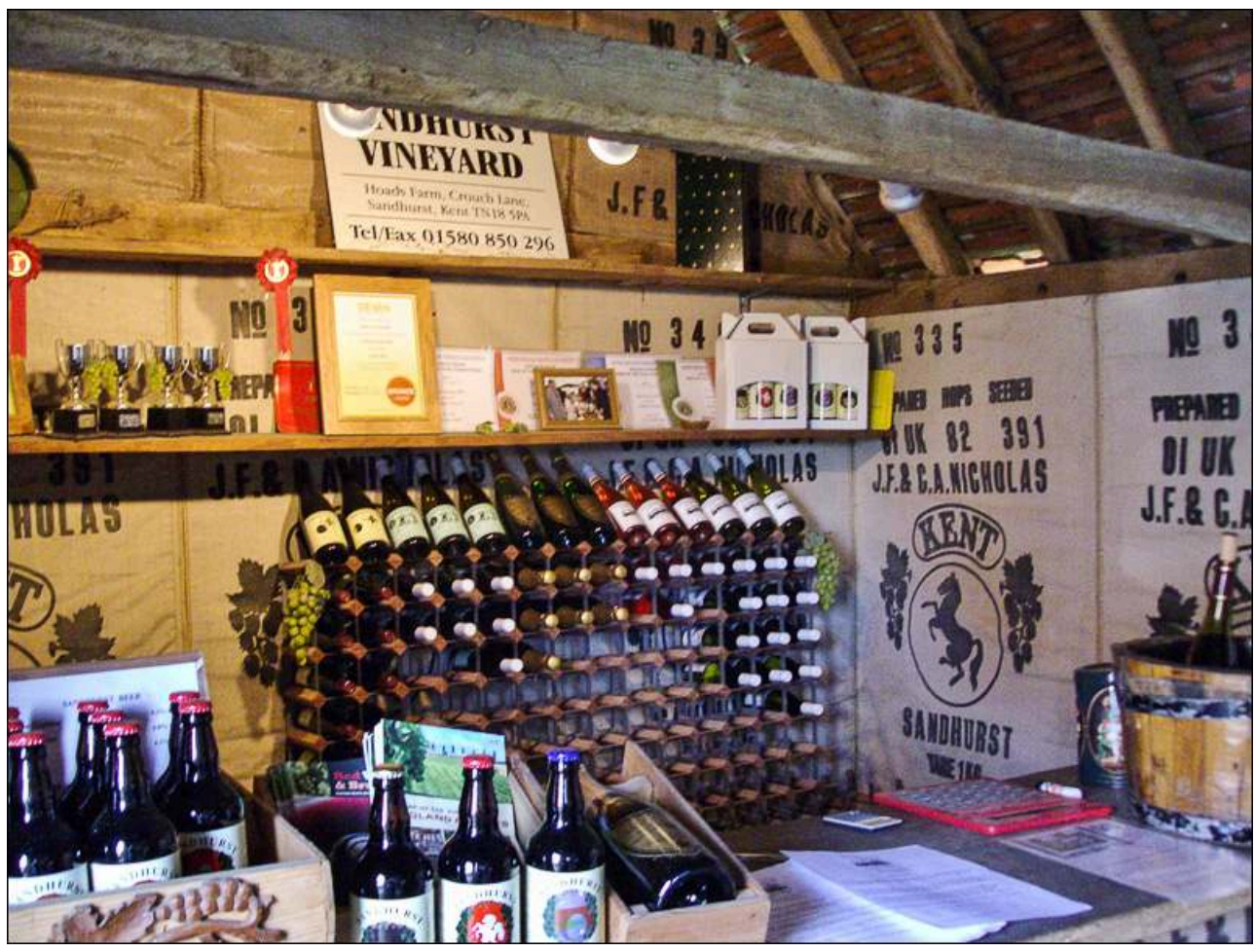

Author: H. Clout, 2012.

Other viticulteurs largely share that view and only open their properties 'by appointment', or on a very few days each year. These objections are of course reasonable, but carefully-tailored 'vineyard tourism' can make interesting contributions to job creation and diversification of the rural economy.

\section{Conclusion}

During the past six decades, viticulture and wine making in England and Wales entered the most recent phase of their fragmented history. They have not only experienced an important renaissance but have achieved some remarkable successes with premium table wines and sparkling wines that sell at premium prices through the best retailers in the land (Pitte, 2004). Yet, at present, the vineyards of England and Wales contribute a mere 0,3 per cent of the wine purchased by the wine-drinking public of the United Kingdom, whose taste for cheap, New World wines seems insatiable. English table wines will never be able to compete in that sector of the market, and in the last analysis, it will require consistent demonstration to convince purchasers that the finest English sparkling wines are of equal quality to Champagne. In the future, increased temperatures associated with 'global warming' may generate environmental conditions that permit a further expansion of viticulture in England and Wales, especially on the North Downs, the Chiltern hills, Salisbury Plain, the South Downs and the High Weald, and in parts of the Thames Valley (Foss et al., 2010; Kenny \& Harrison, 1992; Spellman, 1999; Holland \& Smit, 2010). However, milder winters may well have the negative effect of enabling pests and infections to flourish rather than being killed under cold conditions (Tate, 2001; Selley, 2008). Other pre-requisites for the success of viticulture 
in England and Wales in the future will include adequate capital, entrepreneurial flair, and expertise in vine growing and wine making, and convincing wine drinkers in the United Kingdom that English wines are worth paying extra for.

\section{BIBLIOGRAPHIE}

Ambrosoli M., 1997. The Wild and the Sown: botany and agriculture in Western Europe, 1350-1850. Cambridge University Press, Cambridge, $460 \mathrm{p}$.

Banks G.A. \& Overton J., 2010. Old World, New World? Reconceptualising the worlds of wine. Journal of Wine Research, $n^{\circ} 21$, p. 51-75.

Boodle J., 1992. UK Quality Wine Scheme. Journal of Wine Research, n³, p. 249-251.

Brock R.B., 1949. Outdoor grapes in cold climates. Tonbridge Press, Tonbridge, 80 p.

Brown A.G. \& Meadows I., 2000. Roman vineyards in Britain: finds from the Nene valley and new research. Antiquity, n 74 , p. 491-492.

Brown A.G., Meadows I., Turner S.D. \& Mattingly D.J., 2001. Roman vineyards in Britain: stratigraphic and palynological date from Wollaston in the Nene valley, England. Antiquity, $\mathrm{n}^{\circ} \mathrm{75}$, p. 745-757.

Carlsen, J., 2004. A review of global wine tourism research. Journal of Wine Research, nº 15, p. 5-13.

Carus-Wilson E., 1947. The effects of the acquisition and of the loss of Gascony on the English wine trade. Historical Research, $\mathrm{n}^{\circ} 21, \mathrm{p} .145-154$.

Darby H.C. \& Campbell E.M.J., 1962. Domesday Geography of South-East England. Cambridge University Press, Cambridge, 658 p.

Darby H.C., 1977. Domesday England. Cambridge University Press, Cambridge, 416 p.

Denbies Estate information: www.denbies.co.uk/htm ; and various printed brochures.

English Wine Producers, 2011. Statistics: www.englishwineproducers.com/stats.htm

Foss C., Morris D., Burnside N. \& Ravenscroft N., 2010. Champagne comes to England: assessing the potential of GIS in the identification of prime vineyard sites in south east England. Royal Institute of Chartered Surveyors, London, $20 \mathrm{p}$.

Holland T. \& Smit B., 2010. Climate change and the wine industry. Journal of Wine Research, $\mathrm{n}^{\circ} 21$, p. 125-136.

Hooke D., 1990. A note on the evidence for vineyards and orchards in Anglo-Saxon England. Journal of Wine Research, $\mathrm{n}^{\circ} 1$, p. 77-80.

Howley M. \& Van Westering J., 2008. Developing wine tourism: a case study of the attitude of English wine producers to wine tourism. Journal of Vacation Marketing, $\mathrm{n}^{\circ} 14, \mathrm{p} .87-95$.

Hyams E., 1949. The Grape Vine in England. Bodley Head, London, 208 p.

Hyams E. (ed.), 1953. Vineyards in England. Faber, London, 229 p. 
Ilbery B.W., 1983. The renaissance of viticulture in England and Wales. Geography, nº 68 , p. 341-344.

Ilbery B.W., 1985. Factors affecting the structure of viticulture in England Wales. Area, $\mathrm{n}^{\circ} 17$, p. $147-154$

Kenny, G.J. \& Harrison P.A., 1992. The effects of climate variability and changes on grape suitability in Europe. Journal of Wine Research, $n^{\circ} 3$, p. 163-183.

Meikle, J., 2012. Top vineyard cancels 2012 vintage. The Guardian, 11 October, p. 7.

O’Brien H., 2011. Traveller's guide: English vineyards. The Independent, 1 October .

Ordish G., 1953. Vine Growing in England. Hart-Davis, London, 128 p.

Ordish, G., 1977. Vineyards in England and Wales. Faber, London, 186 p.

Pelham R.A., 1936. Medieval foreign trade: eastern ports. In Darby H.C. (ed.), An Historical Geography of England before A.D. 1800. Cambridge University Press, Cambridge, p. 298-329.

Pitte J-R., 1990. Vins des brumes : la renaissance de la viticulture dans les îles Britanniques. In Huetz de Lemps A., Pitte J-R., De Planhol X. \& Roudié P., Les Vins de l'impossible. Glénat, Grenoble, p. 31-35.

Pitte J-R., 2000. La nouvelle planète des vins. Annales de Géographie, n 109, p. 340-344.

Pitte J-R., 2004. La nouvelle géographie des vins français. Bulletin de la Société Géographique de Liège, $\mathrm{n}^{\circ} 44$, p. 25-31.

Richardson O. \& Dennis C., 2003. United Kingdom vineyards sector case study. British Food Journal, $\mathrm{n}^{\circ} 105$, p. 634-652.

Selley, R., 2008. The Winelands of Britain: past, present and prospective. Dorking, Petravin, $120 \mathrm{p}$.

Skelton S., 2001. The Wines of Britain and Ireland. Faber, London, $531 \mathrm{p}$.

Spellman G., 1999. Wine, weather and climate. Weather, 54, 230-239.

Spellman G. \& Field K., 2002. The changed fortunes of United Kingdom viticulture? Geography, $\mathrm{n}^{\circ} 87$, p. 324-330.

Tate A.B., 2001. Global warming's impact on wine. Journal of Wine Research, n 12, p. 95-109.

Turner S., 2010. Networks of learning within the English wine industry. Journal of Economic Geography, $\mathrm{n}^{\circ} 10$, p. 685-715.

Unwin T., 1990. Saxon and early Norman viticulture in England. Journal of Wine Research, $\mathrm{n}^{\circ} 1$, p. 61-75.

Unwin T., 1991. UK wine: from table wine to quality wine? Journal of Wine Research, $\mathrm{n}^{\circ} 2$, p. $143-150$.

Unwin T., 1994. European wine sector policy and the UK wine industry. Journal of Wine Research, $\mathrm{n}^{\circ}$ 5, p. 135-146.

Williams D., 1936. Medieval foreign trade: western ports. In Darby H.C. (ed.), An Historical Geography of England before A.D. 1800. Cambridge University Press, Cambridge, p. 266-297.

Williams D., 1977. A consideration of the evidence for viticulture in Britain. Britannia, $\mathrm{n}^{\circ} 8$, p. 327-334. 


\section{RÉSUMÉS}

Cet article analyse le passé et le présent de la viticulture en Angleterre et au Pays de Galles. Ces vignobles et établissements vinicoles n'y représentent qu'une partie infime de l'ensemble de la production viticole. En dépit de leur faible représentativité sur la scène mondiale, ils ont connu un succès modeste au cours des siècles passés et connaissent depuis les soixante dernières années un regain grâce aux efforts d'un nombre restreint de pionniers, dont les actions sont étudiées ici. La vigne moyenne est extrêmement petite, mais il existe également de plus grandes entreprises commerciales qui produisent des vins de table de qualité et des vins mousseux, quoiqu'en petite quantité. Quelques opérateurs ont développé le tourisme viticole de manière originale afin de contribuer à la diversification rurale. Les implications du "réchauffement global » peuvent favoriser le développement de la viticulture en Angleterre et au Pays de Galles dans les années à venir pourvu que les conditions de capital, de talent, de flair entreprenarial et de marché soient ouvertes.

This article sketches the past and present of viticulture in England and Wales. These vineyards and wineries represent only a tiny fraction in the global spectrum of vine growing. Despite their insignificance on the world scene, they enjoyed modest success in past centuries, and experienced a revival over the past six decades due to the efforts of a small number of pioneers whose contributions are examined here. The average vineyard is extremely small, but there are also larger commercial enterprises that produce high quality table wines and sparkling wines, albeit in small quantities. Some operators have developed 'vineyard tourism' in imaginative ways to contribute to rural diversification. The implications of 'global warming' may well favour viticulture in England and Wales in future years, provided that capital, skill, entrepreneurial flair and market demand are forthcoming.

INDEX

Keywords : vineyards, wine, tourism, England, Wales

Mots-clés : vigne, vignoble, vin, tourisme, Angleterre, Pays de Galles

Thèmes : Sur le Champ - Sur le Terrain

\section{AUTEUR}

\section{HUGH CLOUT}

Hugh Clout, hughdclout@aol.com, is professor emeritus of human geography, University College London. 